UDC 81'373.23

Submitted: 12.07 .2020

LBC 81.053 .16

Accepted: 02.12.2020

\title{
NATIONAL-AND-CULTURAL SPECIFICITY OF BIBLICAL ANTHROPONYMS IN THE COMPOSITION OF SPANISH AND RUSSIAN PHRASEOLOGICAL UNITS: DYNAMIC ASPECT
}

\author{
Oksana V. Fedosova \\ Moscow State Linguistic University, Moscow, Russia \\ Marina V. Kutieva \\ Plekhanov Russian University of Economics, Moscow, Russia
}

\begin{abstract}
The article presents a synchronous comparative analysis of the semantic structure of biblical anthroponyms Matusalén / Mafusail (Methuselah), Adán / Adam, Lázaro / Lazar as part of the Spanish and Russian phraseological units. The research aims at determining and comparing the national-and-cultural specifics of biblical anthroponyms in the Spanish language worldview against the background of the Russian one, and elucidates the cognitive basis of this specificity. The methods of phraseological identification, vocabulary definitions analysis, functional-and-pragmatic interpretation have been used. The main methods applied are component, discursive, linguo-cultural and comparative analysis. It is concluded that national-and-cultural specificity of biblicalanthroponyms in the Spanish language picture of the world is manifested in the contradiction between the actual and etymological meanings of biblical anthroponyms, in the stylistic detraction of biblical images, their habitation and desacralization with the predominance of pejorative assessment. In Russian linguoculture, biblical anthroponyms mostly retain their original etymology, relate to moral categories and internal characteristics of a person, while in Spanish they are associated with external, physical characteristics. In everyday Spanish discourse, there is a further expansion and detraction in the semantics of bibleisms, their reinterpretation within the tendency to carnivality, resulting from implementation of humorous attitude to reality comprehension.

Key words: anthroponym, bibleism, phraseology, meaning, connotation, language worldview, national mentality.

Citation. Fedosova O.V., Kutieva M.V. National-and-Cultural Specificity of Biblical Anthroponyms in the Composition of Spanish and Russian Phraseological Units: Dynamic Aspect. Vestnik Volgogradskogo gosudarstvennogo universiteta. Seriya 2. Yazykoznanie [Science Journal of Volgograd State University. Linguistics], 2021, vol. 20, no. 1, pp. 89-100. (in Russian). DOI: https://doi.org/10.15688/jvolsu2.2021.1.7
\end{abstract}

\section{НАЦИОНАЛЬНО-КУЛЬТУРНАЯ СПЕЦИФИКА БИБЛЕЙСКИХ АНТРОПОНИМОВ В СОСТАВЕ ИСПАНСКИХ И РУССКИХ ФРАЗЕОЛОГИЗМОВ: ДИНАМИЧЕСКИЙ АСПЕКТ}

\author{
Оксана Витальевна Федосова \\ Московский государственный лингвистический университет, г. Москва, Россия \\ Марина Викторовна Кутьева \\ Российский экономический университет им. Г.В. Плеханова, г. Москва, Россия
}

Аннотация. В статье представлен синхронный компаративный анализ семантической структуры библейских антропонимов Matusalén / Maфycauл, Adán / Adaм, Lázaro / Лазарь в составе фразеологизмов ис- 
панского и русского языков. В целях определения национально-культурной специфики библейских антропонимов в испанской языковой картине мира на фоне русской языковой картины мира, выяснения когнитивной основы такой специфики использованы методы фразеологической идентификации, словарных дефиниций, функционально-прагматической интерпретации, а также методы компонентного, дискурсивного, лингвокультурологического и компаративного анализа. Сделаны выводы о том, что национально-культурные особенности библеизмов-антропонимов в испанской языковой картине мира проявляются в противоречии между их актуальным и этимологическим значениями, в стилистическом снижении библейских образов, их обытовлении и десакрализации с преобладанием пейоративной оценки. В русской лингвокультуре библеизмы-антропонимы в основном сохраняют свои первоначальные значения, соотносятся с моральными категориями и внутренними характеристиками человека, тогда как в испанской лингвокультуре они ассоциируются с внешними, физическими признаками. В обиходном испанском дискурсе происходит дальнейшее расширение и снижение семантики библеизмов, их переосмысление в русле карнавальности как следствие реализации смеховой установки в интерпретации действительности.

Ключевые слова: антропоним, библеизм, фразеология, значение, коннотация, языковая картина мира, национальный менталитет.

Цитирование. Федосова О. В., Кутьева М. В. Национально-культурная специфика библейских антропонимов в составе испанских и русских фразеологизмов: динамический аспект // Вестник Волгоградского государственного университета. Серия 2, Языкознание. - 2021. - Т. 20, № 1. - C. 89-100. - DOI: https://doi.org/ 10.15688/jvolsu2.2021.1.7

\section{Введение}

Библейские образы и сентенции, бесспорно, отражают важнейшие концепты общехристианской культуры, как и всякой национальной культуры, развившейся в лоне христианства, независимо от его разновидности, и принявшей в качестве культурного кода тот вид мировоззрения, который был заложен в канонических книгах Старого и Нового Завета. В национальных языках данный культурный код наиболее наглядно отражен в так называемых библеизмах (антропонимах и топонимах библейского происхождения) и библейских фразеологизмах, которые в силу общей культурной основы имеют не национальный, а универсальный характер, что позволяет исследователям квалифицировать данные языковые единицы как «europeísmos culturales» [Corpas Pastor, 2003, p. 279], «widespread idioms» [Piirainen, 2005; 2012] или традиционно относить их к фразеологическим интернационализмам [Молотков, 1977, с. 219]. Их идентификация и интерпретация представителями разных культур имеют универсальный характер. Так, в большинстве языковых картин мира царь Ирод предстает аллегорией деспотизма и жестокости, апостол Фома - неверия, святой Иов, ставший редкой фигурой в современном русском дискурсе, - бесконечного терпения, а Самсон - силы и мужественности. Эти имена-универсалии входят в состав фра- зеологических единиц (далее - ФЕ) в большинстве европейских языков.

Однако наряду с общей основой, определяющей универсальность значения ФЕ библейского происхождения, семантика, выраженная, как правило, антропонимом, часто по-разному преломляется в разных языковых картинах мира. Отталкиваясь от архетипа, библейские антропонимы как особый класс лексических единиц претерпевают разнообразные семантические сдвиги и приращения [Дубровина, 2002; Жолобова, 2004]. Данные процессы в языке определяются особенностями национальной ментальности и происходят, образно говоря, под ее «давлением», проявляясь прежде всего в обиходном дискурсе как наименее кодифицированном и подвижном с точки зрения изменения словарного состава. Отбор библейских образов и основанных на них фразеологизмов, а также их рекуррентность и вариативность неизбежно определяются особенностями национального мышления, характера и мировосприятия. Так, один и тот же библейский персонаж или сюжет в одном языке может дать жизнь высоко рекуррентному библейскому фразеологизму, а в другом языке воплотиться нефразеологическим образом или вообще кануть в Лету. Например, в испанской языковой картине мира силач Самсон стал денотативным источником фразеологизма Más fuerte era Sansón y le venció el amor (букв. 'Самсон был сильнее, но и его 
сразила любовь'), а младший сын Иакова и Рахили Вениамин - оборота El Benjamín de la familia (букв. 'Вениамин семьи'), обозначающего самого любимого и самого младшего члена семьи. Обе эти ФЕ не имеют эквивалентов в русской языковой картине мира.

Однако в большей степени национальная ментальность проявляет себя при переосмыслении библейских образов-антропонимов, что неизбежно проецируется на семантическую структуру идиоматических оборотов с компонентом-библеизмом, предопределяя их различия в национальных языках уже на уровне денотата. Это влечет за собой и различия в коннотативной составляющей денотативносигнификативного макрокомпонента ФЕ.

В рамках данной статьи мы поставили перед собой взаимосвязанные цели: определение национально-культурной специфики библейских антропонимов в испанской языковой картине мира в сопоставлении с русской языковой картиной мира и выявление когнитивной основы этой специфики. На достижение этих целей направлено решение следующих задач: 1) установить актуальные значения конкретных антропонимов-библеизмов и их коннотативную составляющую в испанских и русских фразеологизмах; 2) сопоставить семантическую структуру фразеологизмов библейского происхождения в испанском и русском языках; 3) определить основу структурно-семантических различий и коннотативной составляющей денотативносигнификативного макрокомпонента ФЕ в испанском и русском языках.

\section{Методология и источники исследования}

Обозначенные нами цели и задачи определили материал, источники и методы исследования. В качестве материала для анализа были выбраны библеизмы-антропонимы Matusalén, Adán и Lázaro как денотативносигнификативные макрокомпоненты ряда рекуррентных ФЕ современного испанского дискурса и их соответствия в русском языке.

Источниками материала послужили толковые и фразеологические словари русского и испанского языков, а также дискурсивный контент испанских интернет-форумов, совре- менной испанской периодики, беллетристики и художественной литературы.

Основными методами исследования стали методы фразеологической идентификации, словарных дефиниций, компонентного анализа, интерпретации, дискурс-анализ, а также метод компаративного анализа, который позволяет выявить культурную специфику библейских антропонимов и основанных на них фразеологических единиц в национальных языковых картинах мира.

\section{Результаты и обсуждение}

\section{Matusalén - Мафусаил}

Рассмотрим в качестве примера испанский фразеологизм ser más viejo que Matusalén - букв. 'быть древнее, чем Мафусаил'1, варианты: vivir más años que Matusalén - букв. 'жить дольше, чем Мафусаил' и tener más años que Matusalén - букв. 'иметь больше лет, чем Мафусаил'. Смысловое ядро данной ФЕ, ее интегральная сема выражены библеизмом-антропонимом Matusalén (Мафусаил), значение которого согласно «Словарю испанского языка Испанской Королевской Академии» (DRAE) определяется как «hombre de mucha edad» - «человек в преклонном возрасте» / «старый человек». Это же значение зафиксировано в двуязычных испанско-русских словарях в следующей трактовке: «древний старец; долгожитель» (БИРС, с. 498).

В современном испанском дискурсе наблюдается модификация в структуре семантики библеизма-антропонима Matusalén за счет подмены денотата путем метафорического переноса значения с человека на предмет при сохранении основной сигнификативной семы 'почтенный возраст'. Так, образ библейского старца используется для обозначения территорий проживания долгожителей: tierra de Matusalén (Vizoso) - букв. 'земля Мафусаила'; для того, чтобы подчеркнуть солидный срок выдержки алкогольного напитка: Descubren que el ron cubano Matusalem tiene su origen en Lloret de Mar (El periódico) - букв. 'Обнаружено, что местом происхождения кубинского рома-Мафусаила является испанская провинция Lloret de Mar'; этим же именем ис- 
панские биологи назвали мутацию, тестируемую ими на мухах и наделяющую последних изрядной сопротивляемостью: La mutación Matusalén otorga a la mosca de la fruta gran longevidad y Resistencia (Carmena) - 'Мутация Мафусаил увеличивает жизнь фруктовых мушек и их устойчивость к болезням'. Разгневанные испанские туристы в Индии не могли уснуть в душном номере из-за шума, производимого старым кондиционером. В своем отзыве они сравнивают этот бытовой прибор с Мафусаилом: Aire acondicionado más viejo que Matusalén (Rampratap Palace) - 'Кондиционер древнее Мафусаила'. К образу Мафусаила обращаются журналисты испанской газеты «El Раís», анализируя предложенную правительством новую политику: Ya podemos decir que la nueva política es más vieja que Matusalén (El País) - 'Теперь видно, что эта новая политика древнее Мафусаила'.

Задержавшийся на своем посту до преклонных лет, кубинский лидер Фидель Кастро также нередко удостаивался прозвища Мафусаил: Bromeando en serio ¿Fidel Castro Matusalén? La Biblia nos cuenta en el libro de Génesis, que Matusalén, el hombre más viejo que ha existido sobre la tierra, vivió 969 años. Pues bien, hace ya como dos meses, más o menos, me parece haber leído en este mismo periódico, que el dictador cubano Fidel Castro, en la opinión de su médico personal, era un hombre muy fuerte y que viviría por lo menos 140 años. Esto si lo dejan... pues no creo que los isleños lo soporten tanto (Sarbelio) - 'Ну а если всерьез? Может быть Фидель Кастро, на самом деле, Мафусаил? В библейской книге Бытия говорится, что Мафусаил был самым старым человеком из всех, когда-либо живших на земле. Он прожил 969 лет. А я около двух месяцев назад читал, кажется, в этой же газете, что, по мнению личного врача Фиделя Кастро, он очень крепкий человек и проживет как минимум 140 лет. Но это, если ему позволят... не думаю, что жители острова будут его столько терпеть'.

Семантика библеизма «Мафусаил» в испанском национальном дискурсе распространяется не только на поле «человек», но также на семантическое поле «время», высвечивая в нем значения рудиментарности и архаичности. Так, К. Фор, автор женской истори- ко-политической энциклопедии, считает обязательный женский домашний труд явлением, давно изжившим себя, и квалифицирует его как атрибут времен Мафусаила: es preciso que la república de los soviets alivie el destino de la mujer trabajadora y la libere de obligaciones domésticas que se remontan a los tiempos de Matusalén (Fauré, p. 452) букв. 'Необходимо, чтобы советская республика облегчила участь трудящейся женщины и освободила ее от обязанностей домашнего труда, которые восходят к временам Мафусаила'.

Количество вариантов использования библейских антропонимов в испанском дискурсе велико. Приведенные выше примеры показывают, насколько легко оперируют библеизмами испанцы, используя их в самых неожиданных контекстах для выражения как позитивной, так и негативной оценки, нередко переиначивая в смеховом аспекте, модифицируя первичную семантику образов и изначально заложенную в них коннотацию. В современном испанском дискурсе семантическая структура библейского антропонима Matusalén меняется: первичный денотативный компонент «долгожитель» / «старый человек» - с заложенной в нем изначально мельоративной коннотацией, ассоциирующейся с такими чертами достигшего преклонных лет человека, как благочестие и мудрость, заменяется денотатом - неодушевленным объектом на основе единственного признака «старость». При этом коннотация в дискурсе приобретает, за редкими исключениями, прямо противоположный, пейоративный оттенок.

Отдельного комментария заслуживает пример, в котором упоминается Фидель Кастро. Здесь переосмысление связано с травестийностью, возникающей в результате совмещения несовместимых образов благочестивого библейского старца Мафусаила и лидера кубинской революции, убежденного коммуниста и атеиста. Коннотация, возникающая в результате такого наложения образов, обретает иронический характер и подразумевает негативную оценку, что раскрывается и в дополнительном комментарии со стороны автора высказывания Л. Сарбельо (Sarbelio).

Доказательством трансформации значения лексемы Matusalén в составе фразеоло- 
гизма является тот факт, что она зафиксирована рядом словарей и других академических источников. В универсальной энциклопедии испанского языка «Сопена» (EUS) отражена расширенная семантика фразеологизма ser más viejo que Matusalén и указано, что основная сема этого антропонима - «быть старым» - распространяется не только на человека, но и на неодушевленные объекты: ser una persona o cosa muy antigua o de mucha $e d a d$ - букв. «быть очень древним человеком или вещью». Этот фразеологизм приводится с пометой «coloquial», что свидетельствует о принадлежности данной ФЕ к разговорному стилю речи.

Словарь испанского языка «Саламанка» (DSLE) также указывает на принадлежность этой ФЕ к разговорному регистру, отмечая, кроме того, ее экспрессивный и зачастую сниженный характер: «intensificador», «frecuentemente peyorativo». В качестве синонимов приводятся слова longevo «долголетний, долговечный», vetusto «ветхий, дряхлый» и vejestorio «старикашка, старикан; старый хрыч; развалина». Два последних синонима имеют ярко выраженную экспрессивную, уничижительную окраску. Словарь испанского сленга «Diccionario del Argot: El Sohez» (DA) также включает антропоним Matusalén со значением «тuу viejo» - 'очень старый' и с пометой «ехрr.». Таким образом, испанские лексикографические источники, зафиксировав новое значение данной единицы, закрепили ее актуальное образное переосмысление.

Иную картину мы наблюдаем в русском языке, где представлена эквивалентная единица Мафусаилов век / Мафусаиловы года. Мы находим ее практически во всех толковых и фразеологических словарях. В «Новом толковом словаре русского языка» Т.Ф. Ефремовой приведены следующие ее значения: 1. долгая жизнь; долголетие; 2. глубокая старость (Ефремова). В академическом «Словаре русского языка» под редакцией А.П. Евгеньевой данная ФЕ фиксируется в вариантах жить Мафусаилов век / Мафусаиловы лета (или годbl) - с пометой «шутл.» в значении 〈жить чрезвычайно долго» (СРЯ, т. 4, 1988, c. 238). «Фразеологический словарь русского литературного языка» А.И. Федорова снабжает данный фразеологизм пометой «устар.», которая указывает на то, что данная словарная единица вышла из активного употребления (ФСРЛЯ, с. 483). В «Большом словаре русских поговорок» фразеологическое выражение жить / прожить Мафусаилов век (век Мафусаила) в значении «о чьем-либо исключительном долголетии» также характеризуется как книжное и устаревшее (БСРП, с. 421). Толкования с пометой, указывающей на устаревший характер и принадлежность книжному стилю, содержатся и в других современных толковых и фразеологических словарях русского языка. В некоторых лингвистических словарях, как видно из приведенных данных, имеется помета «шутл.», которая косвенно также относит данную словарную единицу и к разговорной речи.

Особое место в толковании библейских антропонимов принадлежит специализированному «Энциклопедическому словарю библейских фразеологизмов», составленному К.Н. Дубровиной, которая выделяет два вектора в значении ФЕ (прожить) Мафусаилов век / Мафусаиловы года: 1) «исключительное долголетие кого-либо»; 2) «что-либо очень старое и ветхое» (ЭСБФ, с. 349-350). Автор этого словаря также указывает на книжный характер фразеологического оборота.

Действительно, в русской речевой культуре библейские антропонимы и основанные на них фразеологизмы традиционно относились к книжной речи. Если они и упоминались в разговорной речи, то не часто и, как правило, в шутливой форме, на что указывает помета «шутл.» в некоторых словарях. Однако следует отметить существенное различие между шутливым характером использования библейских антропонимов в русской разговорной речи и ироническим - в испанской: это различие заключается в наличии / отсутствии оценки и ее качестве. Исследуемые единицы в шутливом употреблении в русской разговорной речи выражают добрую насмешку без какой-либо оценки, позитивное отношение со стороны говорящего к предмету высказывания или его реципиенту; ирония же, как известно, всегда включает пейоративную оценочность, поскольку выражает скрытую насмешку.

В современном русском обиходном дискурсе рассматриваемую ФЕ и лежащий в ее 
основе библеизм-антропоним следует считать уже вышедшими из активного употребления. Тем не менее и сегодня некоторые беллетристы изредка упоминают их: Русским людям при такой политике надо бы жить мафусаилов век, чтобы всего дождаться, но средняя продолжительность жизни в России отстает даже от слаборазвитых стран Средней Азии (Горская).

Таким образом, проведенный нами компаративный анализ показывает модификацию антропонима-библеизма Matusalén в составе испанской ФЕ. Искажение первичной семантики манифестируется в стилистическом снижении. В дискурсе данные ФЕ часто подвергаются смеховой трансформации и приобретают дополнительную уничижительную коннотацию. Под влиянием карнавальности, характеризующей коллективную испанскую ментальность, образ библейского старца Мафусаила в испанской картине языковой картине мира и дискурсе утратил свою благообразность, был лишен всяческого почтения и перемещен в сферу повседневной действительности, обслуживаемую разговорным стилем. Мы наблюдаем изменение денотативно-сигнификативного макрокомпонента ФЕ через расширение семантики денотата, когда первичный денотат - человек в почтенном возрасте, старик - заменяется каким угодно неодушевленным объектом. Применительно же к человеку в летах фразеологизм ser más viejo que Matusalén приобретает экспрессивно-уничижительную коннотацию, переводя библеизм Matusalén в разряд жаргонизмов и слов с ярко выраженной пейоративной окраской.

\section{Adán - Adaм}

Библейский антропоним Adán в составе оборота ser un Adán согласно «Словарю испанского языка Испанской Королевской Академии» имеет значение «hombre desaliñado, sucio o descuidado» (DRAE) - «неряшливый, грязный, неаккуратный или неопрятный человек» и принадлежит разговорному регистру речи. В других словарях приводятся схожие значения: «haraposo» - «оборванный, одетый в лохмотья» и «hombre apático у descuidado»«апатичный, вялый, небрежный человек» (DLE), «hombre sucio, que no cuida su aspecto exterior» (DSLE) - «грязный человек, не заботящийся о своем внешнем виде». Словарь испанского языка «Саламанка» отмечает не только принадлежность данной единицы разговорному стилю («Uso / registro: coloquial»), но и фиксирует у этого слова уничижительную коннотацию («Pragmática: peyorativo») (DSLE). Данный библеизм также включен в состав словаря жаргона испанского языка «El Sohez», где фиксируются его значения «desaseado, desastrado, sucio» (DA) «нечистоплотный, оборванный, несчастный».

Антропоним-библеизм Adán выступает в качестве денотативно-сигнификативного макрокомпонента в ряде рекуррентных фразеологизмов испанского обиходного дискурса: ser un Adán / adán - букв. 'быть Адамом / адамом', estar hecho un Adán / adán - букв. 'стать Адамом / адамом'; 'быть как Адам / адам', parecer un Adán / adán - букв. 'казаться Адамом / адамом' (DDR; Wordreference). Например: Estás hecho un adán: llevas una ropa sucia y sin planchar, no te afeitas desde hace cinco dias y vas mal peinado (Spanish Podcast) - 'Ну ты адам! На тебе грязная, мятая одежда, и дней пять уж ты не брит и не чесан'.

Оборот-сравнение с Адамом надежно укоренен в испанском обыденном узусе и встречается при воспроизведении живой разговорной речи в новеллистике. Приведем пример из творчества классика испанского нарратива Бенито Переса Гальдоса: Isabelita y Alfonsín pasaron corriendo. Iban sofocados, sudorosos... "¡Hija, cómo estás!... - dijo Rosalía, deteniendo a la niña. - Tienes la cara como un cangrejo cocido... Ahora corre aire... métete en casa; no te constipes... ¿Y este granuja...? ¿Ve usted cómo viene?, todo roto y hecho un Adán. Mire usted qué rodillas... Si se le pusiera traje de hierro lo mismo lo rompería... (Pérez Galdós) - 'Изабелита и Альфонсин пробежали мимо, запыхавшиеся и потные. <...>. «Дочка, что с тобой?! - сказала Розалия, останавливая девочку. - Ты красная, как рак... А тут сквозняк! ... Иди в дом, не простудись! ... А этот безобразник...? Вы только поглядите на него! Весь рваный, чумазый (букв. 'вылитый Адам'). Только посмотрите на его коленки... На него хоть железный костюм надень, все равно порвет!' 
Такой семантический поворот для русскоговорящего человека чреват когнитивным шоком, ведь аксиоматичной и само собой разумеющейся в русскоязычной стихии видится нам связь антропонима Адам с категориями наготы, первородного греха и/или давности лет. Так, лексикографические и академические источники свидетельствуют о том, что в русской языковой картине мира за библеизмом $A \partial а м$ закреплены следующие значения: 1) «человек вообще», «человек во плоти»; 2) «грешник»; 3) «человек, падкий на соблазн» (ТСЖВЯ т. 1, с. 5); «долгоживущий», «мужчина вообще», «современный мужчина», «спутник жизни», «близкий друг», «нагой человек» [Кузнецова, 2011; Цао, Фоменко, 2016]. Зафиксированы также устойчивое сочетание от Адама / разг. c Адама - «(начинать сообщение) с предыстории чего-либо, издалека», которое в современных словарях дается с пометами «шутл.» и «устар.» (ТСЖВЯ, т. 1, с. 5; СРЯ, т. 1,1985 , с. 24 ; Мокиенко), и речевой оборот это было при Адаме со значением «в старину» (ТСЖВЯ, т. 1, с. 5).

Так, библеизм $A \partial а м$ в русской языковой картине мира сохранил свои первичные ветхозаветные значения: «человек», «мужчина», «грешник», «нагой человек». В указанных значениях в современном обиходном дискурсе он не является рекуррентным, хотя и используется как название салонов одежды, журналов, фирм, причесок и даже кулинарных изысков. Фразеологизмы Адамова голова («череп»), Адамовы слезы («водка»), Адамовы веки («Глубокая древность») (ЭСБФ, с. 20-23), совлечь с себя ветхого Адама («духовно обновиться») (ЭСБФ, с. 609), а также от Адама / с Адама и Eвы («издавна») (ЭСБФ, с. 576), согласно словарным пометам, вышли из активного употребления и признаны устаревшими.

В испанском языке мы наблюдаем замену первичного денотата - «человек, мужчина, грешник, нагой человек»- денотатом, основанным на ассоциативных признаках: «грязный, лохматый, небритый, безвольный». Значимо и снижение регистра использования данной единицы вплоть до перемещения ее в разряд жаргонизмов. В испанском обиходном дискурсе антропоним Adán имеет ярко выраженную уничижительную коннотацию.

\section{Lázaro - Лазарь}

Семантически близким антропониму Adán в испанском языке оказался антропоним Lázaro. Это имя библейского персонажа, страдавшего проказой. Библеизм-антропоним Lázaro имеет значения: «lazarino, leproso»; «mendigo», «pobre andrajoso», «hombre muy pobre y vestido de andrajos» (DRAE; БИРС, c. 463; EUS) - «прокаженный»; «бедняк», «оборванец»; «нищий», «одетый в лохмотья». Это имя является смыслообразующим для ФE: estar hecho un Lázaro - букв. 'быть, как Лазарь', 'стать Лазарем'. Ее вариант - estar hecho un San Lázaro / sanlázaro - реализует значения: 1) «быть покрытым язвами, ранами»; 2) «страдать редкой, трудно излечимой болезнью» (БИРС, с. 463; EUS). Для обыденного дискурса характерен семантический сдвиг с подменой денотата. Например: Sacaron el perro del pozo y vieron que estaba hecho un lázaro (EUS) - 'Когда собаку достали из колодца, увидели, что она вся израненная'. Другой вариант этой ФЕ: estar más llagado que Lázaro / tener más llagas que un Lázaro - букв. 'иметь больше язв на теле, чем Лазарь'. О таком страдальце скажут: Debe tener una enfermedad rara porque está hecho un Lázaro/está más llagado que Lázaro y los médicos no lo pueden curar (DELE, p. 257) 'Должно быть у него какая-то редкая болезнь (букв. 'он стал, как Лазарь'), врачи не могут его вылечить'. Семантически близким к вышеназванным ФЕ является фразеологизм estar más pobre que Lázaro в значении «быть очень бедным» (букв. 'быть беднее, чем сам Лазарь').

Таким образом, в рекуррентных ФЕ современного испанского дискурса антропонимбиблеизм Lázaro актуализируется в значениях, связанных с семантическими полями болезни и бедности, заключая в себе дополнительно коннотацию ярко выраженной экспрессии. Все перечисленные ФЕ характеризуются принадлежностью разговорному регистру речевого общения, что отражено в лексикографических источниках.

Для русской национальной картины мира единственными устойчивыми в семантике библеизма Лазарь являются ассоциации, связанные с попрошайничеством, жалобами и со- 
знательным самоуничижением. Согласно В.И. Далю, Лазарем называли «льстивого и жалобного попрошайку, особый тип нищего; лазарничать означало ластиться, подлещаться, льстиво выпрашивать, канючить, клянчить». Нищие, прося подаяния, пели особый стих - пели Лазаря (ТСЖВЯ, т. 2, с. 234). Таким образом, библеизм Лазарь в русской языковой картине мира приобрел нарицательное значение «нищий, попрошайка, льстец, проныра», что можно объяснить двойной этимологией. Как показывает в своей статье Ю.Б. Камчатнова, антропоним Лазарь был укоренен в русском языке не только через имя персонажа евангельской притчи, но и через народную этимологию, которая определяет все возникшие на его основе фразеологизмы: наобум Лазаря / лазаря (букв. 'на авось', '(на счастье) нищего или же на удачу пройдохи, льстеца' (подробно см.: [Камчатнова, 2014, с. 10]).

Петь Лазаря - значит обманывать, притворяться, прикидываться бедным, больным, несчастным, стараясь разжалобить кого-то: Лазаря петь - «жаловаться на судьбу, прикидываться несчастным» с пометами «разг. неодобр.» (ТСРЯ, с. 444); «жаловаться на судьбу, просить чего-либо, самоуничижаться» (ЭСКСВ); «жаловаться на свою судьбу, участь, прикидываясь несчастным, обиженным; стремиться разжалобить кого-л., вызвать сочувствие, сострадание» с пометами «разг. неодобр.» (СФСРЯ, с. 205).

Таким образом, библейский образ Лазаря в русской языковой картине мира актуализирован через ФЕ в значении «нищий» в проявлении своих низменных и отвергаемых обществом моральных качеств - паразитизма, попрошайничества, обмана, самоуничижения и жалоб с целью получения выгоды. Это внутреннее значение образа обусловливает присущие ему ярко выраженную уничижительную окраску и отрицательную оценку. В испанской же языковой картине мира библейский антропоним Lázaro актуализирован в значениях «больной» и «бедный», отражающих внешнее проявление этих признаков: «покрытый язвами» и «плохо одетый, оборванный». Он включает в себя дополнительную экспрессию, но не содержит какой-либо оценочной коннотации.

\section{Заключение}

Проведенный нами анализ показал, что структура библейских антропонимов Matusalén / Maфусаил, Adán / Adам, Lázaro / Лазарь в составе ФЕ испанского и русского языков имеет существенные различия, в основе которых лежат различия в ценностном подходе к интерпретации одних и тех же образов Священного Писания. Так, образы Мафусаила и Адама в испанской языковой картине мира претерпели, по сравнению с библейским источником, значительную трансформацию, которая коснулась коннотативной и стилистической сферы соответствующих лексем. Семантический сдвиг в обоих случаях произошел в сторону снижения образности и расширения семантики вплоть до переноса значений на предметы быта. Рассмотренные нами библейские антропонимы подверглись травестийному переосмыслению в духе народной карнавальной культуры, в результате чего антропонимы переместились в разряд сниженной разговорной и даже обсценной лексики. В то же время для русского языка характерна приверженность изначальной, библейской трактовке образов, которая сохранилась в денотативно-сигнификативных макрокомпонентах соответствующих ФЕ русского языка, включая коннотативную и стилистическую сферы.

Образ Лазаря отражает иную тенденцию переосмысления. В испанской языковой картине мира он сохранил свои базовые значения: 1) человек, больной проказой; тяжело больной человек; 2) очень бедный человек, одетый в лохмотья. При этом в русской языковой картине мира имела место семантическая трансформация библейского образа Лазаря под влиянием народной этимологии: антропоним становится стилистически сниженным и приобретает негативную коннотацию.

Важно отметить также различия в рекуррентности рассматриваемых библейских $Ф Е$ в соответствующих лингвокультурах. В испанском дискурсе, в первую очередь обиходном и публицистическом, они являются живыми и рекуррентными, о чем свидетельствуют наличие нескольких или многих вариантов каждой такой ФЕ и постоянное пополнение их новыми фразеологическими синонимами, в 
результате чего происходит дальнейшее расширение и снижение семантики библеизмов, их переосмысление в русле карнавальности, где травестийность обнаруживает себя в переиначивании первичных смыслов, в соединении несоединимого, в карнавальном антропоморфизме. В то же время для современного русского дискурса они архаичны и лишь изредка встречаются в книжной речи.

Все выявленные различия в использовании рассмотренных ФЕ являются культурно и национально обусловленными. В русской национальной ментальности библеизмы не утратили своего сакрального значения, восходящего к Священному Писанию, а потому их семантика осталась неизменной. Именно сакральность этой категории слов первоначально являлась для них своеобразной «охранной грамотой», не допуская их стилистического снижения и семантического искажения. В советский же период библеизмы сначала потеряли свою актуальность и культурную значимость в связи с несоответствием коммунистической идеологии, а впоследствии многие из тех, что включают в свой состав компонент-антропоним, и вовсе забылись. Понимание и употребление библеизмов - ветхозаветных имен в советском обществе характеризовало интеллектуальную элиту.

Речевую культуру испанцев, напротив, отличает тенденция к десакрализации и смеховому переосмыслению религиозных образов, что обусловлено национальными особенностями испанской коллективной ментальности, которая является карнавальной в своей основе.

\section{ПРИМЕЧАНИЕ}

1 Здесь и далее перевод наш.

\section{СПИСОК ЛИТЕРАТУРЫ}

Дубровина К. Н., 2002. Контекстуальные значения слов и их перевод на русский язык (на материале поэзии Ф. Гарсиа Лорки) // Вестник РУДН. Серия: Лингвистика. № 3. С. 161-167.

Жолобова А. О., 2004. Творческое преобразование фразеологизмов в тексте // Русская и сопоставительная филология: состояние и перспективы : материалы Междунар. науч. конф., посвящ. 200-летию Казан. ун-та. Казань : Изд-во Казан. ун-та. С. 58-59.

Камчатнова Ю. Б., 2014. О выражении «наобум Лазаря» // Вестник литературного института им. А.М. Горького. № 1. С.10-19.

Кузнецова И. В., 2011. Динамика русских устойчивых сравнений с именами библейских персонажей // Вестник Новгородского государственного университета. № 63. С. 99-102. URL: https://cyberleninka.ru/article/n/dinamikarusskih-ustoychivyh-sravneniy-s-imenamibibleyskih-personazhey (дата обращения: 30.06.2020).

Молотков А.И., 1977. Основы фразеологии русского языка. Л. : Наука. 283 с.

Цао Л., Фоменко И. Б., 2016. Семантика библеизма Адам на страницах современных СМИ // Ученые заметки Тихоокеанского государственного университета. Т. 7. № 3-2. С. 109-113.

Corpas Pastor G., 2003. Acerca de la (in)traducibilidad de la fraseologia // Diez años de investigación en fraseología: análisis sintáctico-semánticos, contrastivos y traductológicos. Madrid : Iberoamericana. P. 275-310.

Piirainen E., 2005. Europeanism, Internationalism or Something Else? Proposal for a CrossLinguistic and Cross-Cultural Research Project on Widespread Idioms in Europe and Beyond // Hermes. Journal of Linguistics. Vol. 35. P. 45-75.

Piirainen E., 2012. Widespread Idioms in Europa and Beyond. Toward a Lexicon of Common Figurative Units. N. Y. : Peter Lang. 591 p.

\section{ИСТОчники}

Горская - Горская Н. Власть нулей. В 2 т. Т. 2. М. : ЛитPес, 2017. 750 c. URL: https://myrt.ru/read/ 494973-vlast-nuley-tom-2.html (дата обращения: 29.06.2020).

Carmena - Carmena E. El creacionismo ¡vaya timo!: Carta a un crédulo. Madrid: Laetoli, 2012. 154 p.

El Pais -El País. 2018. 13 Sep. URL: https://elpais.com/ elpais/2018/09/13/la_voz_de_inaki/1536821744 355831.html (date of access: 28.06 .2020 ).

El Periódico-El Periódico. 2019. 14 de junio. URL: https://www.elperiodico.com/es/extra/20190614/ el-ron-cubano-matusalem-tiene-su-origen-enlloret-de-mar-7505531\#: :text=El\%20ron\% 20cubano\%20Matusalem $\% 2 \mathrm{C} \%$ 20reconocido, poblaci $\%$ C3\%B3n $\% 20$ de $\% 201 a \% 20$ Costa $\%$ 20Brava (date of access: 30.06.2020).

Fauré-Fauré Ch. Enciclopedia histórica y política de las mujeres: Europa y América. Madrid: Ediciones AKAL, 2010. 944 p. 
Pérez Galdos - Pérez Galdos B. La de Bringas. 2003 // Biblioteca virtual universal. URL: https://www. litres.ru/benito-p-rez-gald-s/la-de-bringas/ chitat-onlayn/page-9/ (date of access: 28.06.2020).

Rampratap Palace - Rampratap Palace. 2019. URL: https://www.tripadvisor.com/LocationPhoto DirectLink-g297672-d545798-i49487006 Rampratap_Palace-Udaipur_Udaipur District Rajasthan.html (date of access: 01.07.2020).

Sarbelio - Sarbelio L. Editorial // El Diario de Hoy. 2004. 25 de julio. URL: http://archivo.elsalvador. com/noticias/2004/07/25/editorial/edi5.asp (date of access: 29.06.2020).

Spanish Podcast - Spanish Podcast.Net. URL: https:// www.spanishpodcast.net/estar-hecho-un-adan/ (date of access: 01.07.2020).

Vizoso - Vizoso S. Sanidad al límite en la tierra de Matusalén // El País. 2019. 26 ene. URL: https:// elpais.com/sociedad/2019/01/24/actualidad/ 1548347151_489521.html (date of access: 02.07.2020)

Wordreference - Wordreference. Forum. 2020. URL: https://forum.wordreference.com/threads/estarhecho-un-ad\%C3\%A1n.401555/ (date of access: 28.06.2020).

\section{СЛОВАРИ}

БИРС - Большой испанско-русский словарь = Gran diccionario espacol-ruso / Н. В. Загорская [и др.] ; под ред. Б. П. Нарумова. 8-е изд., стер. М. : Рус. яз. медиа, 2007. 829 с.

БСРП - Большой словарь русских поговорок / В. М. Мокиенко [и др.]. М. : Олма Медиа Групп, 2007. 784 c.

Ефремова - Ефремова Т. Ф. Новый словарь русского языка. Толково-образовательный. В 2 т. T. 1. М. : Рус. яз., 2000. 1210 с. - (Библиотека словарей русского языка).

Мокиенко - Мокиенко В. М. Библеизмы в современной русской речи. Как их правильно понимать и употреблять. М. : Центрополиграф, 2017. URL: https://www.litres.ru/valeriymokienko/bibleizmy-v-sovremennoy-russkoyrechi-kak-ih-pravilno-pon/chitat-onlayn/ (дата обращения: 27.06.2020).

СРЯ - Словарь русского языка. В 4 т. / под ред. А. П. Евгеньевой. 3-е изд. М. : Рус. яз., 19851988. $4 \mathrm{~T}$.

СФСРЯ - Словарь фразеологических синонимов русского языка / В. П. Жуков [и др.] ; под ред. В. П. Жукова. М. : Рус. яз., 1983. 448 с.

ТСЖВЯ - Даль В. И. Толковый словарь живого великорусского языка. В 4 т. М. : ГИС, 1955. 4 т.
URL: http://www.booksite.ru/fulltext/dal/dall/ index.htm (дата обращения: 27.06.2020).

ТСРЯ - Ожегов С. И. Толковый словарь русского языка. 18-е изд. М. : Рус. яз., 1986. 797 с.

ФСРЛЯ - Федоров А. И. Фразеологический словарь русского литературного языка. М. : Астрель : АСТ, 2008. 878 с.

ЭСБФ - Дубровина К. Н. Энциклопедический словарь библейских фразеологизмов. М. : Флинта : Наука, 2010. 808 с.

ЭСКСВ - Серов В. В. Энциклопедический словарь крылатых слов и выражений. М. : ЛокидПресс ; Локид, 2004. 880 c. URL: https:// azbyka.ru/fiction/enciklopedicheskij-slovarkrylatyx-slov-i-vyrazhenij-serov/ (дата обращения: 28.06.2020).

$D A$ - Carbonell Basset D. Diccionario del Argot: El Sohez. N. Y. : McGraw-Hill, 2002. URL: https:// argot_es.academic.ru/ (date of access: 25.06.2020).

DDR - Diccionario de dichos y refranes. URL: https:// sp_sp_dichos_refranes.academic.ru/ (date of access: $26.06 . \overline{2} 020)$.

DELE - Martínez López J. A., Jorgensen A. M. Diccionario de expresiones y locuciones del español. Madrid : Ediciones de la Torre, 2009. $542 \mathrm{p}$.

$D L E$ - Diccionario de la lengua española. URL: https:// espanola.academic.ru/ (date of access: 27.06.2020).

$D R A E$ - Diccionario de la lengua española de Real Academia Española. Madrid : RAE, 2019. URL: https://dle.rae.es/ (date of access: 25.06.2020).

DSLE - Diccionario Salamanca de la Lengua Española. Salamanca : Santillana, 2015. URL: https:// sal_es.esacademic.com/22371/ (date of access: 28.06.2020).

EUS - Enciclopedia universal Sopena: Diccionario ilustrado de la lenqua espanola. Barcelona : Sopena, 1980. URL: https://enciclopedia_ universal.esacademic.com/ (date of access: 26.06.2020).

\section{REFERENCES}

Dubrovina K.N., 2002. Kontekstualnye znacheniya slov i ih perevod na russkij yazyk (na materiale poezii F. Garsia Lorki) [Contextual Meanings of Words and Their Translation into Russian (On F. Garcia Lorca Poetry)]. Vestnik RUDN. Seriya: Lingvistika [Russian Journal of Linguistics], no. 3, pp. 161-167.

Zholobova A.O., 2004. Tvorcheskoe preobrazovanie frazeologizmov $\mathrm{v}$ tekste [Creative Transformation of Phraseologisms in a Text]. Russkaya i sopostavitelnaya filologiya: sostoyanie i perspektivy: materialy Mezhdunar. 
nauch. konf., posvyashch. 200-letiyu Kazan. un-ta [Russian and Comparative Philology. State and Prospects. Proceedings of the International Scientific Conference, Dedicated to the $200^{\text {th }}$ Anniversary of Kazan University]. Kazan, Izd-vo Kazanskogo universiteta, pp. 58-59.

Kamchatnova Yu.B., 2014. O vyrazhenii «naobum Lazarya» [About the Expression "Naobum Lazarya"]. Vestnik literaturnogo instituta im. A.M. Gorkogo [Vestnik of Gorky Literary Institute], no. 1, pp. 10-19.

Kuznetsova I.V., 2011. Dinamika russkih ustoychivykh sravneniy s imenami bibleyskikh personazhey [The Dynamics of Russian Stable Comparisons with the Names of Biblical Characters]. Vestnik Novgorodskogo gosudarstvennogo universiteta [Vestnik of Yaroslav the Wise Novgorod State University], no. 63, pp. 99-102. URL: https:// cyberleninka.ru/article/n/dinamika-russkihustoychivyh-sravneniy-s-imenami-bibleyskihpersonazhey (accessed 30 June 2020).

Molotkov A.I., 1977. Osnovy frazeologii russkogo yazyka [Bases of the Russian Language' Phraseology]. Leningrad, Nauka Publ. 283 p.

Tsao L., Fomenko I.B., 2016. Semantika bibleizma Adam na stranicah sovremennyh SMI [Semantics of Bibleism Adam in the Pages of Modern Mass Media]. Uchenye zametki Tikhookeanskogo gosudarstvennogo universiteta [Scientists Notes of Pacific National University], vol. 7, no. 3-2, pp. 109-113.

Corpas Pastor G., 2003. Acerca de la (in)traducibilidad de la fraseologia. Diez años de investigación en fraseología: análisis sintáctico-semánticos, contrastivos y traductológicos. Madrid, Iberoamericana, pp. 275-310.

Piirainen E., 2005. Europeanism, Internationalism or Something Else? Proposal for a CrossLinguistic and Cross-Cultural Research Project on Widespread Idioms in Europe and Beyond. Hermes. Journal of Linguistics, vol. 35 , pp. 45-75.

Piirainen E., 2012. Widespread Idioms in Europa and Beyond. Toward a Lexicon of Common Figurative Units. New York, Peter Lang. $591 \mathrm{p}$.

\section{SOURCES}

Gorskaya N. Vlast'nuley. V 2 t. [Zeros' Power. In 2 Vols. Vol. 2]. Moscow, LitRes Publ., 2017. 750 p. URL: https://myrt.ru/read/494973-vlast-nuley-tom2.html (accessed 29 June 2020).

Carmena E. El creacionismo jvaya timo!: Carta a un crédulo. Madrid, Laetoli, 2012. 154 p.
El País, 2018, 13 Sept. URL: https://elpais.com/elpais/ 2018/09/13/la_voz_de_inaki/1536821744_ 355831.html (accessed 28 June 2020).

El Periódico, 2019, 14 de junio. URL: https://www. elperiodico.com/es/extra/20190614/el-roncubano-matusalem-tiene-su-origen-en-lloret-demar (accessed 30 June 2020).

Fauré Ch. Enciclopedia histórica y política de las mujeres: Europa y América. Madrid, Ediciones AKAL, 2010.944 p.

Pérez Galdos B. La de Bringas. 2003. Biblioteca virtual universal. URL: https://www.litres.ru/benito-prez-gald-s/la-de-bringas/chitat-onlayn/page-9/ (accessed 28 June 2020).

Rampratap Palace. 2019. URL: https://www. tripadvisor.com/LocationPhotoDirectLinkg297672-d545798-i49487006 Rampratap_PalaceUdaipur_Udaipur_District_Rajasthan.html (accessed 1 July 2020).

Sarbelio L. Editorial. El Diario de Hoy, 2004, 25 de julio. URL: http://archivo.elsalvador.com/ noticias/2004/07/25/editorial/edi5.asp (accessed 29 June 2020).

Spanish Podcast.Net. URL: https://www. spanishpodcast.net/estar-hecho-un-adan/ (accessed 1 July 2020).

Vizoso S. Sanidad al límite en la tierra de Matusalén. El País, 2019, 26 ene. URL: https://elpais.com/ sociedad/2019/01/24/actualidad/1548347151_ 489521.html (accessed 2 July 2020).

Wordreference. Forum. 2020. URL: https://forum. wordreference.com/threads/estar-hecho-unad\%C3\%A1n.401555/ (accessed 28 June 2020).

\section{DICTIONARIES}

Zagorskaya N.V. et al., eds. Bolshoy ispansko-russkiy slovar - Gran diccionario espacol-ruso [Great Spanish-Russian Dictionary]. Moscow, Russkiy yazyk media Publ., 2007. 829 p.

Mokienko V.M. et al. Bolshoy slovar russkih pogovorok [The Great Dictionary of Russian Sayings]. Moscow, Olma Media Grupp Publ., 2007. $784 \mathrm{p}$.

Efremova T.F. Noviy slovar russkogo yazyka. Tolkovoobrazovatelniy. V 2 t. T. 1 [New Dictionary of the Russian Language. ExplanatoryEducational. In 2 Vols. Vol. 1]. Moscow, Russkiy yazyk Publ., 2000. 1210 p. (Biblioteka slovarey russkogo yazyka [Library of Russian Dictionaries]).

Mokienko V.M. Bibleizmy v sovremennoy russkoy rechi. Kak ih pravil'no ponimat' $i$ upotreblyat' [Bibleisms in Modern Russian Speech. How to Understand and to Use Them Correctly]. 
Moscow, Tsentropoligraf Publ., 2017. URL: https://www.litres.ru/valeriy-mokienko/ bibleizmy-v-sovremennoy-russkoy-rechi-kak-ihpravilno-pon/chitat-onlayn/ (accessed 27 June 2020).

Evgenyeva A.P., ed. Slovar russkogo yazyka. V 4 t. [Dictionary of the Russian Language. In 4 Vols.]. Moscow, Russkiy yazyk Publ., 1985-1988.

Zhukov V.P. et al., eds. Slovar frazeologicheskih sinonimov russkogo yazyka [Dictionary of Phraseological Synonyms of the Russian Language]. Moscow, Russkiy yazyk Publ., 1983. $448 \mathrm{p}$.

Dal' V.I. Tolkovyj slovar' zhivogo velikorusskogo yazyka. V 4 t. [Explanatory Dictionary of the Alive Great Russian Language. In 4 Vols.]. Moscow, GIS Publ, 1955. URL: http://www. booksite.ru/ fulltext/dal/dall/index.htm (accessed 27 June 2020).

Ozhegov S.I. Tolkovyj slovar' russkogo yazyka [Explanatory Dictionary of the Russian Language]. Moscow, Russkiy yazyk Publ., 1986. 797 p.

Fedorov A.I. Frazeologicheskij slovar' russkogo literaturnogo yazyka [Fraseological Dictionary of the Russian Literary Language]. Moscow, Astrel Publ., AST Publ., 2008. 878 p.

Dubrovina K.N. Enciklopedicheskiy slovar' bibleiskih frazeologizmov [Encyclopedic Dictionary of Biblical Phraseologies]. Moscow, Flinta Publ., Nauka Publ., 2010. 808 p.
Serov V.V. Enciklopedicheskiy slovar krylatyh slov $i$ vyrazheniy [Encyclopedic Dictionary of Winged Words and Expressions]. Moscow, Lokid-Press Publ., Lokid Publ., 2004. 880 p. URL: https:// azbyka.ru/fiction/enciklopedicheskij-slovarkrylatyx-slov-i-vyrazhenij-serov/ (accessed 28 June 2020).

Carbonell Basset D. Diccionario del Argot: El Sohez. New York, McGraw-Hill, 2002. URL: https:// argot_es.academic.ru/ (accessed 25 June 2020).

Diccionario de dichos y refranes. URL: https:// sp_sp_dichos_refranes.academic.ru/ (accessed 26 June 2020).

Martínez López J.A., Jorgensen A.M. Diccionario de expresiones y locuciones del español. Madrid, Ediciones de la Torre, 2009. 542 p.

Diccionario de la lengua española. URL: https:// espanola.academic.ru/ (accessed 27 June 2020).

Diccionario de la lengua española de la Real Academia Española. Madrid, RAE, 2019. URL: https://dle.rae.es/ (accessed 25 June 2020).

Diccionario Salamanca de la Lengua Española. Salamanca, Santillana, 2015. URL: https://sal_ es.esacademic.com/22371/ (accessed 28 June 2020).

Enciclopedia universal Sopena: Diccionario ilustrado de la lengua espanola. Barcelona, Sopena, 1980. URL: https://enciclopedia universal.esacademic.com/ (accessed 26 June 2020).

\section{Information About the Authors}

Oksana V. Fedosova, Doctor of Sciences (Philology), Associate Professor, Professor, Department of Spanish Language and Translation, Moscow State Linguistic University, Ostozhenka St, 38, 119034 Moscow, Russia, fedossova@yandex.ru, https://orcid.org/0000-0003-4223-4326

Marina V. Kutieva, Candidate of Sciences (Philology), Associate Professor, Foreign Languages Department No. 2, Plekhanov Russian University of Economics, Stremyannyy Lane, 36, 117997 Moscow, Russia, kuteva.mv@rea.ru, https://orcid.org/0000-0002-2952-8349

\section{Информация об авторах}

Оксана Витальевна Федосова, доктор филологических наук, доцент, профессор кафедры испанского языка и перевода, Московский государственный лингвистический университет, ул. Остоженка, 38, 119034 г. Москва, Россия, fedossova@yandex.ru, https://orcid.org/0000-0003-4223-4326

Марина Викторовна Кутьева, кандидат филологических наук, доцент кафедры иностранных языков № 2, Российский экономический университет им. Г.В. Плеханова, пер. Стремянный, 36, 117997 г. Москва, Россия, kuteva.mv@rea.ru, https://orcid.org/0000-0002-2952-8349 